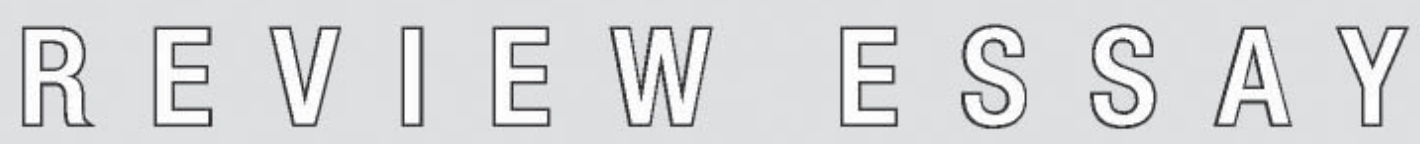

af Thomas Hoffmann

\title{
Neo-orientalisme \\ - om orientalismens postmoderne mutationer
}

Ian Almond 2007: The New Orientalists - Postmodern Representations of Islam from Foucault to Baudrillard. London: I. B. Tauris \& Co Ldt.

To skridt frem og ét tilbage!

To skridt frem og ét tilbage! Det var det mundheld, som faldt mig ind efter at have læst Ian Almonds tankevækkende bog fra 2007. Mundheldet kan også oversættes til følgende ligning: de to skridt er den filosofiske og kunstneriske nyudvikling, som det postmoderne projekt - uanset dyder eller laster - betegner med sine nye måder at analysere og lave kunst på. Det ene tilbageskridt betegner derimod den banale og ærgerlige erkendelse, at fremskridtet måske alligevel ikke er så lineært fremadskridende, men også rummer tilbageløb, forviklinger og deciderede knuder. At nogle af det postmodernistiske projekts fremmeste protagonister synes at bære på en temmelig reaktionær "hemmelighed", der ikke så sjældent er i stik modstrid med projektets frisættende forhåbninger. At det postmodernistiske begrebsapparats forsøg på at destabilisere (eventuelt parodiere) hævdvundne idéhistoriske hierarkier og begreber som identitet, historisk fremskridt, nærvær og betydning ved hjælp af begreber som det Andet, forskellen (le différance), det iterative, hybriditeten og simulakrene igen og igen ender med gentage dén semiotiske kulturneurose, som Edward Said døbte "orientalisme".

Ifølge Almond falder den postmodernisternes kritik af den vesterlandske filosofi og moderne kunst nemlig tilbage på et klassisk orientalistisk mønster, hvor Orienten, islam og muslimerne instrumentaliseres, reduceres og i-tale- 
sættes som et mere eller mindre ambivalent fascinationspunkt - ikke for Orienten, islam eller muslimernes egen skyld, men reelt udelukkende for den vestlige verdens egen skyld. Kort og hårdt sagt: en uhellig alliance mellem euro/occident-centrisme og orientalisme.

Nøgleordet her er naturligvis begrebet orientaslisme, et begreb som nærmest er blevet synonymt med litteraten Idwârd Wadî̀ Sa'îd, bedre kendt som Edward Said. Én af Saids teser var, at den vestlige-kristne verden med dens kuld af antropologer, arabister og Ex Oriente Lux-dyrkende kunstnere siden 1700-tallet har fremmanet en monolitisk, og dybt forvrænget, konstruktion af en nær Orient/Mellemøsten, der som bekendt langtfra er homogen med sig selv, men tværtimod er en ganske heterogen region (med dertil flydende grænser). Orientens indbyggere, skikke og historier skulle indtage rollen som alt det, Europa ikke selv var, men var pirret og frastødt af på én gang - med haremmet som et ærkeeksempel. Således blev orientalisme et tankespind, som på perfid vis - og i samspil med en Vestens kolonialisme - indhyllede østerlændingene i en blanding af realpolitik, administrativ stålnæve og kulturelt hegemoni.

Detaljerne i Saids problematiske værk udelader vi her (de belyses fint i nærværende nummers andre artikler), men lad os nu sige, at Said har en grundlæggende og helt fornuftig pointe i, at det er noget nær umuligt at tale om det Andet, det eksotiske og fjerne, uden at komme til at tale om sig selv og på den måde geråde ud i en vis form for (til tider ondartet) eurocentrisme og intellektuel narcissisme. Hvis denne præmis accepteres, så er Almonds værk interessant læsning. Med andre ord: postmodernisterne har de bedste intentioner og de mest subtile og kritiske begrebsapparater, men de formår alligevel ikke at undslippe orientalismens forjættende diskurs, men ender til syvende og sidst med selv at kolporterer den i ny postmodernistisk udgave. Almond vover ikke selv at koge sin kritik ind til ét udtryk, men i mangel af bedre kunne man eventuelt tale om neo-orientalisme.

Det er en tese, der bør mane til selvransagelse hos dem, som i sikker forvisning om højrefløjens populistiske xenofobier post-9/11, har søgt ideologisk og begrebslig frelse i postmodernismens mere eller mindre esoteriske begrebsapparat. Almond beskæftiger sig ikke med den åbenbare og banale risiko for dæmoniserende ontologier, som trives på højrefløjen. Det er derimod den særlige intrikate form for fare, der ligger i baghold, når man opfatter sine egne intentioner som grundlæggende gode og empatiske. I den generelt venstredrejede postmoderne kritik af den vestligt rundede modernitet ser vi blandt andet, at man af og til tyer til en stereotypificeret opfattelse af islam og muslimer som alternative modbilleder, f.eks. i en entusiastisk retorik om islams "radikale intensitet" (Foucault), dens virile aggressivitet (Nietzsche) og dens uforanderlige inkompatibilitet med den "kapitalistiske globale orden" (Žižek). Det problematiske heri, påpeger Almond, ligger således ikke kun i en intern brist i den postmodernistiske diskurs - tydeligvis et udslag af 
prominent post-nietzscheansk tradition for kulturelt Selbsthass og den eviggyldige ligning om min fjendes fjende er min ven. Det problematiske ligger også lige for, når islam og muslimer bliver puttet i sådanne positivt, omklamrende båse. Derfor er problemkomplekset heller ikke helt det samme som den gamle, klassiske saidianske orientalisme. Der er måske snarere tale om en ny fase i orientalismen, en gedulgt og subtil form for neo-orientalisme?

Det er ovenstående intrikate og gedulgte problematikker, som Almond ønsker at identificere og rette en kritik mod. Med et indledende citat af den romantiske digter Byron (1788-1824) signalerer Almond dog, at neo-orientalismen ligger i forlængelse af den gamle, romantisk orientalisme:

I have seen Mankind in various Countries and find them equally despicable, if anything the Balance is rather in favour of the Turks.

Almond kommenterer herpå:

...the spirit of Byron's gesture - that of an English/European self-critique which partly results in, partly springs from a concerted, selective, at times not wholly convincing sympathy with the Islamic Other - will be found in practically all of the nine writers presented in this book (s. 1).

\section{Almond info}

Lidt baggrundsoplysning om forfatteren. Almond er en udpræget international universitetsnomade, hvilket passer godt til hans nuværende post som lektor i transnational literatures ved Georgia State University, USA. Hans uddannelse er britisk og inden for litteraturvidenskab, men har herefter undervist $\mathrm{i}$ Italien, Tyskland og Tyrkiet. Ud over nærværende bog har han udgivet en bog om sufisme og dekonstruktion (med særligt henblik på Ibn 'Arabî og Derrida) og er i 2009 på vej med to bøger: én om muslimsk-kristne militære alliancer samt en bog om islam i tysk tænkning fra Leibniz til Nietzsche. Hovedvægten af hans udgivelser fokuserer på idé- og litteraturhistoriske forhold, og bøgerne opererer derfor med et ret teoretisk og filosofisk ladet vokabular, ligesom det bestandigt har været den tolkende og eksperimentelle undersøgelse af relationerne mellem den vestlige og islamiske verden, der har spundet bøgernes røde tråde.

\section{Neo-orientalisterne}

Bag The New Orientalists' kunstløse titel gemmer sig et ærkeædrueligt og gennemkritisk, men også fair arbejde med nogle af postmodernismens mest celebre og forkætrede kunstnere og tænkere. Med Nietzsche (1844-1900) som den præ-postmodernistiske patriark, hvis afkom er et broget kuld af skønlitterære forfattere og tænkere. På skønlitteraturens side metafiktionens lille gud, Jorge Luis Borges (1899-1986), sprogkalejdoskopet Salman Rushdie (1947) og den 
melankolske Nobelpris-sufi Orhan Pamuk (1952). På tænkersiden diskursanalysens udtænker og galskabsarkæolog Michel Foucault (1926-1984), dekonstruktionens ikon Jacques Derrida (1930-2004) og psyko-femi-litteraten Julia Kristeva (1941), navngiveren til begreber som intertekstualitet og det abjektale. Endelig også de to filosof-sociologiske enfants terribles, Jean Baudrillard (1929-2007), manden bag teorien om uvirkelighedens virkelighed (simulakrene og hyperrealiteten), og det sidste nye skrig, det slovenske énmandsorkester Slavoj Žižek.

Inden for store dele af den humanistiske forskning udgør såvel ovennævnte tænkere som forfatterne en prominent del af det postmodernistiske panteon. Selvom Baudrillard måske kan kaldes en hastigt døende stjerne, er det generelt navne, der stråler af intellektuel kapital og ekstremt høje citation-rater. Og dét ikke kun inden for universitetets mure, men også som interview- og kronikstjerner i prominente aviser som The Times, Le Monde og Frankfurter Allgemeine. Deres stjernestatus til trods har disse navne og deres filosofisk-sociologiske udkast også fremkaldt kritiske modstemmer. En række forskere - fra Alan Sokal til Habermas - har løbet storm på det postmodernistiske projekt blandt andet ud fra den begrundelse, at det alt for ofte forfalder til pseudo-videnskab, obskurantistisk retorik, ekstremistisk relativisme - og nu altså også orientalisme.

Det er vanskeligt at levere en overordnet karakteristik af disse folk - deres status er netop kommet i stand på grund af deres respektive originale bidrag. Teorierne og den prosa, de udfolder sig i, kører som oftest på de høje nagler, men fælles for dem er vel, at de er særdeles skeptiske over for størrelser som endelig erkendelse og fornuft og over for muligheden for at repræsentere og gengive noget fuldstændigt objektivt og adækvat. For fornuft er også magt, ikke sjældent en undertrykkende eller hegemonisk overmagt, der knap nok bemærkes af nogen, men alligevel gennemsyrer tankeformer og institutioner.

Et andet fællestræk er deres behandling og brug af islam og muslimer. Her er det med Almond ved roret dybt interessant, men også let foruroligende, at erfare, hvordan de med næsten usvigelig sikkerhed svigter deres eget kritiske opdrag. I stedet forfalder de til ret bastante generaliseringer af muslimer og arabere eller slet og ret forbigår dén islamiske Anden, som deres blik for det marginale og uudfoldede ellers burde have tunet dem til. I stedet for at være genuint interesserede $\mathrm{i}$ den islamiske verden iscenesætter de blot islam og muslimer som rekvisitter i en modernitetskritik, der både er moralsk tvivlsom og som nævnt også ganske eurocentrisk. Med andre ord: i stedet for at udøve den kritik, selvkritik og kompleksitetsdyrkelse, som netop deres teorier og tidsånd gjorde en dyd af (og som de og deres tilhængere naturligvis skosede andre for ikke at leve op til), synes de at forfalde til det stik modsatte i lige præcis tilfældet islam - trods goodwill over for muslimer og islam og trods det faktum, at de befandt sig i de øverste lag af ofte prominente universiteter 
og her kunne trække på egentlige islameksperter. Her må det tilføjes, at det mindre er forfatterne end tænkerne, jeg adresserer.

\section{Nedslag i neo-orientalistismens lastekatalog}

Almond har sammensat sine artikler i tre store installments flankeret af en introduktion og en konklusion. Første del hedder Islam og kritikken af moderniteten og inkluderer Nietzsche, Foucault og Derrida. Anden del hedder Islam og postmoderne fiktion og inkluderer Borges, Rushdie og Pamuk. Tredje del hedder Islam, "teori" og Europa. Lad os gennemgå hovedpersonerne i denne rækkefølge og foretage nogle illustrative nedslag.

Alting starter med Nietzsche, den store mistænker, der i rasende dionyssisk prosa gennemhegler den vestlige verdens hævdvundne metafysikker og rationaliteter. I Antikrist slutter Nietzsche med følgende bredside: "De er mine fjender - jeg indrømmer det - disse tyskere: jeg foragter dem..." Overfor sådant et kulturelt selvhad kan andre tider og kulturer fungerer som mere eller mindre utopiske tilflugtssteder. Muslimerne/araberne bliver sammen med romerne, japansk adel, homeriske helte og skandinaviske vikinger "virile" (indtil det misogyne) og militant livsbekræftende, når Nietzsche foretager sine kritikker af kristendom og jødedom. I andre analytiske sammenhænge er Muhammad dog intet andet end en semitisk post-platonist, der manipulerer de frie masser og låser dem fast i love og imperativer. Almonds konklusion er klar: islam er fascinerende, men grundlæggende reduceres den til et rekvisit i et internt europæisk opgør. Særligt ét citat er afslørende. Her skriver den 21-årige Nietzsche til sin søster:

Spørg min gamle kammerat Gersdorff om han har lyst til at tage med mig til Tunesien et års tid eller to... Jeg vil leve et stykke tid blandt muslimerne, og vel at mærke et sted hvor deres tro er mest intens; $p a ̊ d e n$ måde kan mit blik og dømmekraft for alt hvad der er europæisk blive skærpet.

Han kom aldrig længere sydpå end Napoli.

Blandt Nietzsches arvtagere finder vi Foucault. Han tilbragte to år i Nietzsches uindfriede rejsemål. Fra 66-68 befandt Foucault sig i Tunesien. De to år nævnes kuriøst nok kun en passant, men der er applaus til de tunesiske studenterdemonstrationers "voldelighed" og "radikale intensitet". Hvor de parisiske studerende blot brugte marxismen "som en bedre måde at studere virkelighed på", mobiliserede tuneserne "en bemærkelsesværdig moralsk energi." Små ti år senere gentager Foucault sine bifald for Khomeinis iranske revolution, som han oprømt udråber til et oprør fra "imperiernes randområder: [oprør mod] vægten af en global orden. Det er måske den første større opstand mod det planetære system, den mest moderne og gale form for revolte." Ud over at være en retorik, der forgriber værker som Hardt og Negris Empire, ser vi en flig af Foucaults Orient som en massens Orient (jf. det trivialiserede 
begreb "den arabiske gade"), ikke det selvstændigt tænkende individs. Orienten som stedet for den ægte galskabs befriende aktion.

Derrida kommer relativt nådigt gennem Almonds analyser. En tænker som Derrida, der voksede op i Algeriet, forfægter faktisk en kompleksitetens islam, en svimlende mangfoldighed af islamer. Men med denne afsværgelse af essentialisme og ideen om, at man rent faktisk kan tale om islam som en substantiel størrelse, har Derrida egentlig blot tilvejebragt en vifte af islamer, som passer til en hvilken som helst lejlighed. Islam ad hoc - abrahamisk brodermonoteisme, når det passer, og arkaisk terror, når det passer. Herfra er der ikke langt til, at Derridas islam bliver et fata morgana, der forsvinder, når man forsøger at komme nærmere. Almond læser Derridas mangfoldigheds-islam som en islam, der passer ind i et gammelt orientalistisk mønster om islams radikale Andethed, et kultursvimlende arabesk, der udmatter og jager det fokuserede rationelle blik ud af en tangent.

Herefter bevæger vi os over i afdelingen for skønlitteratur. Borges, écrivain préferé af Foucault og Derrida, er i kunstnerisk forstand en postmodernistisk forgængerfigur. Hans skrift er fuld af filosofisk uudgrundelighed og leg med mulige og umulige verdener - alam al-mithal, "allegoriske verdener", et centralt begreb i den mere filosofiske sufisme. Det er også en dybt traditionelt orientalistisk person- og tingsgalleri, Borges tager i brug: fortællingerne svirrer med arabiske og persiske navne, emirer, turbaner, ørkener, falske Muhammad'er, fiktive islamologer m.m. Trods Borges' dybt subtile fortællinger læser Almond alligevel en fundamental frygt for islam (en frygt der dog også falder sammen med mange andre "frygter") ud af hans oeurvre, mest slående i Borges måske mest berømte fortælling, Tlön, Uqbar, Orbis Terties, om et fiktivt encyklopædi der ender med at overtage verdenen og virkeligheden. Allusioner (f.eks. Uqbar der minder om akbar i allahu akbar "Gud er størst") og regelrette referencer til islam (f.eks. når fortælleren åbner den 1001 sider lange encyklopædi med en henvisning til laylat al-qadr, islams "hellige nat" hvor Koranen blev nedsendt til Profeten) og den islamiske verden (det fiktive Tlön beskrives som "en region i Irak eller lilleasien") løber sammen til Europas gamle frygt for at blive overtaget og ind taget af islam.

Salman Rushdie formulerer - i sine fiktive værker såvel som i sine mere nyhedsorienterede output - sig lige så mangfoldigt og "tvetvunget" om islam. Når konteksten er Indiens stærke hindu-fundamentalistiske bevægelser som RSS, Shiv Shena, Mumbais muslim-progromer eller forfatter-kollegaen Naipuls dystre islamanalyser stiller han sig på islams og muslimernes side, fremhævende de moderate elementer i islam, minoritetens sårbare position og den islamiske histories mange subalterne stemmer ("progressive, irreverent, skeptical, argumentative, playful" islam). Men den fatwa-fordømte Rushdie skifter oftere denne modstemme ud med en ganske religion- og islamkritisk stemme, hvor han som en anden anglo-indisk Voltaire svinger pisken over islamisk fanatisme, hindu-had og hjerteløs shari'a diskurs. 
Sidste skønlitterære billede er Orhan Pamuk. Han synes sammen med Rushdie at være den postmodernistiske repræsentant, som vanskeligst lader sig underkaste Almonds tese. Pamuks figurer og miljøer er måske nok stereotypisk melankolske, men det er på den anden side for meget at forlange, at Istanbuliten Pamuk og Bombayiten Rushdies stærke genrebevidstheder ikke må "genre-ficere" den verden, de delsvis er rundet af.

Tredje del, kapitel syv, tager Julia Kristeva under behandling. Kristeva synes at være den af tænkerne, der kommer nærmest en nyvakt semi-nationalistisk europæisme (med Frankrig i spidsen!). Hendes tidlige psykoanalyser om det abjektale (dvs. hvordan subjektets stabilitet opretholdes i kraft af en identificering af det urene, der herefter skal udstødes) ledte hende over til samfunds- og statsanalyser, hvor ideen om abjektale procedurer gentages på kollektivets plan. Ikke desto mindre forekommer hendes udtalelser i de sidste tyve år mere og mere islam-abjektale. På baggrund af især Rushdie-affæren synes Kristeva at være parat til at opgive sit ellers fint-tunede alteritetsapparat og tale om den islamiske verden i vendinger, der ikke levner rum til mellemrummene og Andethedet. Islam beskrives som en ekstremt usammentidig verden, reaktionær og repressiv i en sådan grad, at Europa synes at være det eneste håb for de muslimske masser:

Vi [europæere] må være mere positive - jeg kunne sige mere aggressive - når vi fører vores kultur frem; ...hvis vi ønsker en mediterran fred der ikke skal være en gentagelse af Roms fald alt imens vi oplever en følelse af skyld på baggrund af en indstrømning af ydmygede og krævende arabiske masser. Lad os ikke være flove over europæisk og især fransk kultur...

Som Almond skriver: intentionen er sikkert god nok, men Kristeva synes nærmest at tale for en fortsættelse af det romerske imperium, ligesom hun - ville jeg tilføje - falder ind i et klassisk orientalistisk topos med billedet af de ansigtsløse (nærmest subjektløse) masser, der kræver.

Baudrillard er manden bag ideen om le hyperréel, en kunstig virkelighed (frembragt af massemedier, kapitalisme og spindoktorer), som har overtaget den "gammeldags" virkelighed. Baudrillard fordømmer ikke denne hyperrealitet, men omfavner kynisk-entusiastisk det overfladiske og retoriske. Denne position passer som fod i hose til det gamle orientalistiske tema om Østen som både drømmens og fata morganaets sted, men også snyderiets og forstillelsens sted. Paradoksalt nok forfægter Baudrillard samtidig ideen om, at muslimen er stædig og umulig at overtale i sin hysteriske dogmatisme - en anke som allerede Luther skød muslimerne i skoen. I modsætning til Nietzsche, Foucault og Derrida, der advokerer for en solidaritet med islam, er Baudrillard helt på det rene med islams rene og skære Andethed. Denne Andethed er så til gengæld Vestens egen skyld. Lige som Middelalderens teo- 
loger talte om islam som en Guds svøbe over en fordærvet kristenhed, således ser Baudrillard islam som et instrument for den europæiske kulturs perverse dødsdrift. På den måde er islam og muslimer igen reduceret til at være rekvisitter i en postmodernistisk vestlig selv- eller USA-kritik.

Sidste repræsentant for det postmodernistiske projekt er ikke mindre radikal end Baudrillard. Vi taler selvfølgelig om Žižek, en karismatisk og strategisk labil filosof. Det bliver for omfattende at introducere til Žižeks filosofi, men ét genkommende element er hans forestilling om islams radikale energi (læs: fanatisme), f.eks. følgende analyse af 9/11 fra essaysamlingen Velkommen til virkelighedens ørken:

Det ultimative sigte med angrebene var ikke nogen form for skjult eller åbenlys ideologisk agenda, men - præcist i den hegelianske betydning af begrebet - at (re)introducere den absolutte negativitets dimension i vores dagligliv...(Velkommen til virkelighedens ørken)

Her foretager Žižek en analytisk bevægelser der - med Žižeks forbillede Hegels ord - læser islam som en religion med en "entusiasme for det abstrakte", som en religion, der er konstitueret ved dét, som den akkurat er modstander af. Andre steder i Žižeks ouevre finder man bemærkninger om den palæstinensiske selvmordsbombers mere "intense liv" sammenlignet med dumme joggende yuppier i New York, eller vesterlændinge der er "nedsunkne i dumme nydelser" over for "den radikale muslim... der er villig til at risikere alt." I sin bog Irak - den lånte kedel læser Žižek islam som en religion, der i sin radikale modstand mod modernitet kan forædles til et socialistisk projekt:

Netop fordi islam kan nære de "værste" potentialer i det fascistiske svar til vores nutidige problemstillinger kan det også udgøre stedet for det "bedste". Med andre ord: islam er slet ikke en religion som andre, den har et stærkere social bånd, den modstår integration ind i den kapitalistiske globale orden....

Igen: islam i-tale-sættes som så radikalt uden for nummer, så fuldstændig kontrær, at den er er globale kapitalismes sidste håb for en et selvoopgør, der ender op som en "chance" for at realisere en fremtidig socialisme.

\section{Den intertekstuelle incest og andre laster}

Med The New Orientalists er der er ikke tale om en monografi, der gradvist udfolder og uddyber sin tese. Snarere har den antologiens karakter, hvor forfatteren i de ni hovedkapitler (hvoraf flere har været trykt tidligere som selvstændige artikler i tidsskrifter) belyser ræsonnementer og stilistiske greb i de forskellige oeuvres, henholdsvis de filosofiske, litterære og litteraturvidenskabelige. At hvert kapitel er bundet op på et bestemt navn er medvirkende til, at 
analyserne og diskussioner forbliver grundlæggende forpligtede på at forstå lige netop disse skribenters tekster. Denne loyalitet over for det singulære formår Almond ikke desto mindre momentvist at overskride og samle op i bemærkninger, der peger tilbage til foregående kapitler og i den forstand bidrager til en fornemmelse af progression i Almonds tekst. Enhver antologis noget fragmenterede præg får altså her - og i tandem med den overordnede tese om en lumsk neo-orientalisme - et lærerigt idé- og litteraturhistorisk schwung. Man bliver med andre ord ligeså klog på de individuelle forfatterskaber som på det overordnede emne: orientalismens postmoderne mutationer.

Lad os opsummere Almonds fire vigtigste konklusioner, som kommenteres i bogens afsluttende kapitel. For det første: det fremmede og ubekendte, in casu islam og muslimer, approprieres i kritikken af det gement hjemmevante, in casu Europa og den "vesterlandske" tænkning. Heraf følger Almonds næste pointe: trods identificeringen og den ofte empatiske besyngelse af en given islamiske Andethed afslører denne diskurs sig i sidste instans som en europæisk "hjemmefødning". Vi får med andre mere at vide om postmodernistiske strømninger og partisansynspunkter end om islam og muslimer. Den tredje konklusion viser, hvor sekulært orienteret det postmodernistiske projekt i bund og grund er: trods de kvasi-teologiske toner man kan møde hos en Nietzsche, Derrida eller Baudrillard, er det primært en social og antropologisk islam, der sættes i sving i de postmodernistiske tekster. Den næstsidste konklusion, som Almond kommer frem til, er ganske dyster; nemlig at den kritiske brod, som det postmodernistiske projekt abonnerer på, tenderer at skride ud af en nihilistisk tangent, som forbindes med en særlig islamisk aura eller élan. Hvor det islamistiske terrorangreb i žižeksk optik bliver synonym med den autentiske "Handling" over for en bogstavtynget humanisme, hvor islam bliver til en revolutionær "radikal intensitet" på foucaulsk, eller hvor en gedulgt islam bliver til en hemmelig verdenskonspiration. Det ligner betænkeligt meget en armchair scholar's drøm om en aktivistisk, nihilistisk energi, hvor Muslimen simpelthen bare handler frem for at analysere alt til dødens kedsommelighed. Men det er samtidig en drøm, "som berøver islam sin dybde og kompleksitet og i stedet genopfører den i en ren 1800-tals tomhed og umenneskelighed" (s. 202). Den sidste vigtige iagttagelse hos Almond er hans påvisning af den næsten incestuøse intertekstualitet, som har styret den postmoderne écriture. Selvom der er produceret store mængder forskningslitteratur om islam, muslimer og Mellemøsten, synes disse tænkere og skribenter at være tilfredse med at læse og genlæse hinanden. Indrømmet, det kommer der mange stimulerende iagttagelser ud af, men det forbliver reelt - med filosoffen Levinas' ord - "en udvidelse af Det Sammes Imperium". Mere hårdt: et eurocentrisk Weltinnenraum af generaliseringer og ideosynkrasier, der her og der kaster blændede lys på aftenslandets filosofisk sorte huller, men som reelt forbliver dilettantisk og patroniserende uengageret i den islamiske verden. 
Og min egen konklusion? Under læsningen blev jeg løbende imponeret over Almonds empatiske dekonstruktion af dekonstruktionen/postmodernisme og denne strømnings i grunden ambivalente forhold til islam. I stedet for at vi forfalder til en ny kynisme over for det postmoderne projekt (eller tilstand?), som let kan resultere i neo-konservative og et anti-saidianske ressentiment á la Martin Kramer, vælger jeg at bruge denne bogs indsigter som et opdrag til "os orientalister" om at turde teoretisere ligeså dristigt som postmodernisterne - men med en ansvarlighed og videnskabelige præcision over for islam og muslimer, som er passende for vores faglighed. Yderligere: vi må have intellektuelt overskud til at være ydmyge mht. vores egen teoridannelsers transparens og kritiske rækkevidde, ligesom vi også må berede os på at dekonstruere og intervenere muslimske og mellemøstlige receptioner af dekonstruktioner, saidismer, subalteriteter og hvad ved jeg.

Thomas Hoffmann

E-mail: th@teo.au.dk

Andre bøger af Almond:

Sufism and Deconstruction. A Comparative study of Derrida and Ibn 'Arabi. Routledge, 2004.

History of Islam in German Thought: From Leibniz to Nietzsche. Routledge, 2009.

Two Faith, One Banner: When Muslims Marched with Christians Across Europe's Battlegrounds. Harvard University Press, 2009. 